\title{
Odlišné sociální klima učitelských sborů ZŠ v rozmanitých podmínkách práce školy ${ }^{1}$
}

\author{
Jitka Jursováa ${ }^{\text {, Petr Urbánek }}{ }^{\mathrm{b}}$, Markéta Váchová ${ }^{c}$ \\ a,b Technická univerzita v Liberci, Fakulta př́rodovědně-humanitní a pedagogická, \\ Katedra pedagogiky a psychologie \\ c Univerzita Karlova, Pedagogická fakulta, Ústav výzkumu a rozvoje vzdělávání
}

Redakci zasláno 2.1.2019 / upravená verze obdržena 10.5. 2019 /

/ k uveřejnění přijato 18. 5. 2019

\begin{abstract}
Abstrakt: Cílem empirické studie je v kontextu zjištěných parametrů sociálního klimatu identifikovat a popsat shody a rozdíly mezi vybranými učitelskými sbory ZŠ v jejich charakteristikách a fungování. Jde tedy o hledání prríčin zjištěných hodnot klimatu učitelského sboru v konfrontaci evidentních znaků učitelského sboru se znaky, jejichž vliv je méně zjevný, skrytý. Výzkumný postup směřuje od kvantitativního výzkumu, z něhož byla využita získaná data jako východiska, k procedurám kvalitativního výzkumu. $Z$ typologického výběru vzešly dvě dvojice učitelských sborů základních škol. První dvojice s krajně odlišnými (příznivými a nepříznivými) a druhá s obdobnými (příznivými) hodnotami sociálního klimatu. Analýze byly podrobeny způsoby sdílení vize a fungování školy, styl vedení a jeho geneze, mezilidské vztahy a komunikace, angažovanost učitelů a její podpora. Na př́kladu vybraných učitelských sborů se ukazuje, že i přes srovnatelné hodnoty jejich sociálního klimatu se školy mohou lišit v organizaci a vytváření podmínek práce. Jako nápadné se ukázaly zejména rozdíly v pedagogickém vedení, a to i u dvojice podobných škol. Klíčovým atributem pro optimální fungování vedení se ukazuje být soulad stylu vedení se specifiky každého jednotlivého učitelského sboru. Za zásadní pro kvalitu sociálního klimatu sboru lze považovat vytvářenou shodu na hlavních principech chodu školy, sdílení jasné vize rozvoje, podporující styl vedení a cílevědomě vytvářený prostor pro práci učitele. Způsoby, jak dosáhnout optimálního sociálního klimatu sboru, se mohou lišit a vytvářejí ve specifických podmínkách života každé školy zcela originální a komplikovaný organismus.
\end{abstract}

Klíčová slova: základní škola, učitelský sbor, sociální klima, kvalitativní výzkum, komparace

1 Př́spěvek je jedním z výstupů výzkumného projektu (GA ČR 16-10057S) Stabilita a proměny učitelských sborů ZŠ a byl podpořen GA ČR. 
Význam učitele pro výsledky školy nebývá odbornou sférou ani veřejností obecně zpochybňován. ${ }^{2}$ Odborníci zabývající se u nás tematikou učitelství a profesním rozvojem učitelů (Průcha, 2002; Vašutová, 2004; Spilková \& Vašutová, 2008; Lazarová et al., 2011; Píšová, 2011; Starý et al., 2012; Lukášová, 2015, a řada dalších) vždy zdůrazňují osobu učitele jako klíčového aktéra, který se rozhodující měrou podílí na efektech školního vzdělávání. Spolu s organizací práce školy, tj. se způsobem jejího řízení a vedení lidí ve škole, jsou profesní dovednosti a osobnostní charakteristiky jednotlivých učitelů pro výsledky vzdělávání zcela zásadní.

Význam fungování kolektivu učitelů jako celku již tolik doceňován nebývá. K učitelskému sboru (jeho charakteristikám, personální konstelaci, profesním vztahům, fluktuaci) se česká odborná a výzkumná sféra obrací již s podstatně menším akcentem. Kromě občasného explicitního uchopení tématu (např. Urbánek, 2011; Urbánek, Dvořák, \& Starý, 2014; Rozkovcová \& Novotová, 2018; Urbánek, 2018) je zájem o učitelské sbory rozvíjen spíše nepřímo v souvislosti s problematikou učitele (Švaříček, 2009; Čech, 2011; Lazarová et al., 2011; Novotný \& Brücknerová, 2016, aj.). Pedeutologická literatura, byt' zkoumá učitele zpravidla v osobním i profesním kontextu nutně vázaném na sbor, se učitelskými sbory explicitně zabývá jen sporadicky. Přitom nejen individuální kvalita každého jednoho učitele, ale též personální skladba učitelského sboru, stupeň synergických vazeb nebo klima ve sboru jsou určujícími faktory procesuální i rezultativní stránky práce školy. Profesní a sociální charakteristiky učitelského sboru navíc představují směrem k žákům model fungující komunity se silným výchovným nábojem v oblasti skrytého kurikula.

České základní školy, v nichž zkoumáme učitelské sbory, jsou přirozeně ve srovnání se zahraničním prostředím specifické. Charakteristiky a fungování sborů budou touto skutečností nejspíš významně ovlivněny. Tak napřr. sít' základních škol v Česku je poměrně hustá; plně organizované základní školy jsou členěny na dva vzdělávací stupně „pod jednou střechou“ (Urbánek, 2011); management škol disponuje „silnou autonomií a nízkou odpovědností" (Dvořák, Urbánek, \& Starý, 2014) aj. Z důvodů těchto i dalších specifik se naše stat' opírá převážně o zdroje z českého prostředí a zahraniční prameny využívá zejména v závěrech ke konfrontaci s empirickými zjištěními.

2 Decizní sféra v deklarativní rovině význam učitele nezpochybňuje, svými reálnými kroky tak ale mnohdy činí. Např. aktuálně připravovaný návrh novely zákona 563/2004 Sb., o pedagogických pracovnících, význam práce učitele zjevně zpochybňuje, snižuje-li požadavky na jeho přípravu a kvalifikaci. 


\section{Učitelské sbory a jejich sociální klima}

Kvalitu (relativně ustálených) interpersonálních vztahů a sociálních procesů, které fungují v daném učitelském sboru, reprezentuje fenomén sociálního klimatu. Obecné vymezení sociálního klimatu však není triviální (Lašek, 2001, s. 40-43) a má různé kontexty (Mareš, 2003, s. 87-97). Definičně není pojem zcela sjednocen, což vyplývá z jeho různorodých konceptualizací (Ježek, 2003, s. 2-31). Sociální klima je možné sledovat v různých rovinách, skupinách, zasahuje odlišné entity, a tedy také školu a učitelský sbor (Lašek, 1995). Pro potřeby tohoto textu a pro specifikum učitelského sboru chápeme klima s oporou o Mareše (2001, s. 583) jako sociálněpsychologickou proměnnou, kterou vnímají, prožívají, hodnotí a reflektují učitelé uvnitř sboru s přesahy $\mathrm{k}$ realitě řízení školy a vedení lidí. Klima učitelského sboru tedy vyjadřuje souhrn subjektivních názorů učitelů na vztahy a procesy ve sboru a uvnitř školy, na způsoby řízení a na míru identifikace učitelů se sborem. ${ }^{3}$ Implicitně zahrnuje prožitkovou linii od minulosti k budoucím očekáváním. V souvislosti se subjektivní povahou sociálního klimatu zdůrazňovali průkopníci teoretických konceptů (např. Halpin \& Croft, 1963) důležitost vnímaného chování, nebot' je právě tím, co ve skutečnosti řídí jedincovy reakce. My dodáváme, že vnímané klima potenciálně ovlivňuje dění ve sboru. Učitelský sbor je ve srovnání se školou (se skupinou všech aktérů školy) podstatně menším, konzistentnějším a uchopitelnějším celkem, navíc $s$ významným sociálním vlivem v rámci celé školy. Proto se domníváme, a i závěry jiných nálezů to potvrzují (např. Urbánek, 2008, s. 102), že sociální klima je výstižným indikátorem kvality práce sboru a v přesazích i chodu celé školy. Diagnosticky pokrývá sociální podstatu učitelského sboru jako celku, dostatečně citlivě odkrývá jeho fungování a může predikovat i jeho další sociální vývoj. ${ }^{4}$

\footnotetext{
Sociální klima učitelského sboru chápeme v souladu s definovanými znaky slovníkového vymezení sociálního klimatu školy, avšak modifikované v kontextu specifičnosti učitelského sboru a využívaného diagnostického nástroje (OCDQ-RS). Pedagogický slovník vymezuje sociální klima školy jako „sociálněpsychologickou proměnnou vyjadřující kvalitu interpersonálních vztahů a sociálních procesů, které fungují v dané škole tak, jak ji vnímají, prožívají a hodnotí učitelé, žáci, příp. zaměstnanci školy." (Průcha, Walterová, \& Mareš, 2013, s. 125). Podle Mareše (2001, s. 583) zahrnuje obsahově termín klima školy „ustálené postupy vnímání, prožívání, hodnocení a reagování všech aktérů školy na to, co se ve škole odehrálo, odehrává nebo má v budoucnu odehrát“.

4 Sociální klima učitelských sborů není v českém prostředí zkoumáno často. Navíc je téma klimatu sborů specifické na různých stupních škol. Existují výzkumné nálezy sociálního klimatu směrované např. ke sborům mateřské školy (Kotátková, 2009), základní školy (Lašek, 2001; Urbánek, 2006), střední školy (Lašek, 2001) i školy vysoké (Grecmanová et al., 2013).
} 
Předmětem našeho výzkumného zájmu jsou učitelské sbory v základních školách, se svými charakteristickými atributy. Ty vyplývají ze všeobecně vzdělávací a kultivační funkce základní školy (tematicky široký záběr učiva, výrazný výchovný aspekt), z délky vzdělávání, která implikuje značný věkový rozptyl vyučovaných žáků (a tím i jejich kognitivní a sociální heterogenitu), z povinného charakteru vzdělávání, který vymezuje motivační rámec práce s žáky apod. Uvedená specifika mají dopad na charakter činností i vzájemné spolupráce učitelů. Učitelský sbor je tak napřs. (v plně organizované základní škole) typicky strukturován na subsbory dvou stupňů s odlišnou organizací výuky, jinou oborovou specializací, s různorodým předmětovým zaměřením učitelů druhého stupně, s požadavkem nezanedbatelné profesní kooperace učitelů, nutné spolupráce s rodiči žáků atd. Kromě shodných či velmi podobných znaků, kterými jsou učitelské sbory základních škol charakterizovány, mezi nimi také existují rozdíly, a to mnohdy velmi výrazné.

Odlišnosti mezi učitelskými sbory se mohou týkat (1) charakteristik učitelů v rámci celého sboru (např. počet učitelů ve sboru, podíl kvalifikovaných, věková struktura, průměrná délka praxe, stupeň feminizace sboru, podíl dojíždějících na pracoviště, míra fluktuace, kvalita vztahů a interakcí mezi učiteli); (2) individuálních vlastností a profesní kvality každého jednoho učitele ve sboru (napřs. profesní zkušenosti, typ vzdělávací dráhy, učitelovo pojetí výuky, osobnostní profil, učitelovo privátní zázemí); (3) širšího kontextu podmínek, ve kterých sbory fungují (geneze sboru, lokalizace školy, způsob řízení a vedení lidí, architektura školy, vztahy vedení ke zřizovateli aj.). Kombinace všech těchto charakteristik sborů, vlastností jejich učitelů a podmínek, ve kterých sbory fungují, vytváří ve své specifičnosti a komplikovanosti originální sestavu (konstelaci) každého učitelského sboru. Přes uvedené odlišnosti ale učitelské sbory musí v principu pracovat se stejnou kategorií žáků a naplňovat tytéž funkce.

Rozdílnosti učitelských sborů otevírají řadu otázek souvisejících s jejich fungováním v prostoru školy jako specifické organizace (Pol, 2007, s. 14-21). Pro potřeby naší výzkumné studie vycházíme (a) z tzv. evidentních znaků učitelských sborů, které byly již výzkumně zjištěné, resp. jsou zjevné, dostupné a nám již známé. Týkají se především sociálního klimatu, případně i demografických charakteristik učitelského sboru a vedení a lokálních poměrů školy. Jsou určující pro typologický výběr sborů. Předpokládáme, že další 
(b) tzv. skryté znaky vybraných učitelských sborů určitou mírou ovlivňují sociální klima ve sborech, a jsou tedy předmětem kvalitativního šetření. ${ }^{5}$

Náš příspěvek se snaží konfrontovat zjištěné hodnoty sociálního klimatu učitelského sboru (evidentní znaky) s jeho teprve zjištovanými charakteristikami a podmínkami (se skrytými znaky). V těchto souvislostech jsme si položili dvě zásadní výzkumné otázky:

V01: Vjakých charakteristikách se odlišují učitelské sbory s extrémními rozdíly (krajními hodnotami) sociálního klimatu a proč je klima mezi nimi natolik rozdílné?

V02: Vjakých charakteristikách se shodují učitelské sbory s podobnými hodnotami sociálního klimatu a proč je klima v obou sborech podobné?

Cílem naší empirické studie je v kontextu zjištěných parametrů sociálního klimatu identifikovat a popsat shody a rozdíly mezi vybranými učitelskými sbory ZŠ v jejich charakteristikách a fungování.

\section{Metodologie}

\subsection{Výzkumný design}

K naplnění cíle studie bylo primárně využito empirických dat shromážděných v rámci řešeného výzkumného projektu. Ten byl zaměřen mj. na zjištování sociálního klimatu učitelských sborů základních škol (Urbánek et al., 2017). Nálezy tohoto kvantitativního šetření (2016) dovolily vytvořit pořadí zkoumaných sborů $(\mathrm{N}=125)$ podle hodnot celkové otevřenosti sociálního klimatu a pro následnou kvalitativní analýzu a komparaci umožnily výběr příhodných typů škol. K plastickému a citlivému vyjádření tak komplexního fenoménu, jakým je sociální klima uvnitř organizace, resp. v učitelském sboru, byly ze získaných dat vytěženy dílčí hodnoty klimatu a z nich byl pro každý sbor konstruován grafický profil. K dispozici byly také výsledky opakovaného dotazníkového šetření (2018), a to pro identifikaci dynamiky sociálního klimatu a verifikaci dat.

\footnotetext{
Průcha (2015, s. 126-127), když vymezuje oblasti pedagogické evaluace, nezapomíná ani na edukační prostředí a považuje evaluaci klimatu škol z hlediska tématu i diagnostiky za zvláštní problematiku. Ve shoděs jinými autory též připomíná, že každá škola má specifické, resp. svébytné klima. Faktory, které jej ovlivňují, kategorizuje na objektivní (velikost a lokalizace školy, socioekonomické složení populace žáků a jejich rodičů) a subjektivní (styl uplatňovaného řízení, který je podmiňován velikostí a složením učitelského sboru).
} 
Metodologickou podstatou níže popisovaného výzkumu je kvalitativní analýza charakteristik a fungování čtyř vybraných učitelských sborů v konfrontaci se zjištěnými hodnotami sociálního klimatu. Důraz je proto kladen na kvalitativní procedury. Kvantitativní výsledky sociálního klimatu (celkový index otevřenosti) jsou pro následnou kvalitativní analýzu především východiskem pro typologický výběr sborů. Přesto ale konstelace hodnot dílčích dimenzí, grafický profil klimatu a jeho vývoj či variabilita výpovědí sboru, které vyprodukovala kvantitativní fáze, obohacují hloubku šetření a přispívají k objasnění fungování šetřených sborů. Ve shodě s Bergmanem (2011) proto v naší konstrukci vnímáme využitou kombinaci obou výzkumných přístupů jako kompatibilní a rezultativně velmi užitečnou. Se smíšeným výzkumným designem korespondují i formulace výzkumných otázek. Kombinace kvalitativních a kvantitativních metod má ve smyslu triangulace i jistý validační potenciál (Schründer-Lenzen, 2013, s. 152). Naše šetření představuje smíšený výzkumný design s fázovým modelem simultánní kombinace a s akcentem na kvalitativní procedury, tedy podle Hendla (2005, s. 276-278) modifikovaně ve schématu quan +QUAL.

\subsection{Výzkumné metody a nástroje}

Sociální klima učitelských sborů bylo (mimo námi dále popisovaný výzkum) zkoumáno pomocí dotazníkového nástroje OCDQ-RS (Kottkamp, Mulhern, \& Hoy, 1987). Pro české poměry byl dotazník adaptován Laškem (2001, s. 119-129). ${ }^{6}$ Z hlediska naší analýzy je podstatné, že konstrukce dotazníku generuje pět dílčích dimenzí klimatu. První dvě dimenze, suportivita (SUP) a direktivita (DIR), tedy učiteli vnímaná podpora a pevnost vedení, vyjadřují vztahy sboru k vedení školy. Tři následující dílčí dimenze klimatu zjištujují učiteli vnímané vztahy uvnitř sboru, orientaci na podporu žáků a vyjadřovanou identifikaci učitelů s prací školy (angažovanost/ANG), vnímanou profesní zátěž (frustrace/FRUS) a vyjadřované bližší přátelské vztahy mezi učiteli (intimita/INT). Z prvních čtyř dimenzí (SUP, DIR, ANG, FRUS) je vypočítáván celkový index otevřenosti, který představuje souhrnnou hodnotu sociálního klimatu učitelského sboru (IO). Data z šetření sociálního klimatu učitelských sborů byla východiskem pro typologický výběr sborů ZŠ.

6 Dotazník je optimálním výzkumným nástrojem k identifikaci subjektivně kolektivního fenoménu sociálního klimatu. Dotazník OCDQ-RS má 34 zjištovacích položek, respondenti se k výrokům vyjadřují na čtyřstupňové škále. Dotazníky byly administrovány z procedurálních i technických důvodů kontaktně na výběrovém souboru 125 ZŠ v ČR (náhodný stratifikovaný výběr) v první polovině roku 2016. 
Ze čtyř vybraných základních škol byla vytěžena data z realizovaných případových studií. Podle kategorizace Mareše (2015, s. 119-121) se jedná o exploratorně vícepřípadovou studii učitelského sboru, o níž pojednávají např. Dvořák a kol. (2010). Terénní výzkum byl realizován ve dvou etapách, na jaře a na podzim 2017. V každé škole probíhal dva dny v tříčlenném výzkumném týmu. Hlavními aktéry výzkumu byli učitelé, vedení škol a žáci těchto škol. Při dodržení všech etických pravidel výzkumu byly využity následující výzkumné metody a techniky: (1) hloubkový polostrukturovaný rozhovor s vedením školy (ředitel/ředitelka, zástupkyně), s výchovnou poradkyní, s vybranými učiteli prvního a druhého stupně; (2) dotazník ${ }^{7}$ pro ředitele školy zjištoval názory na práci se sborem a pohyby učitelů; (3) skupinový rozhovor (focus group vždy se šesti žáky 8. nebo 9. ročníku); (4) strukturované pozorování vyučovacích hodin u vybraných učitelů; (5) zúčastněné pozorování průběhu provozní porady; (6) nestrukturované pozorování vybavení a provozu školy; (7) analýza školní a žákovské dokumentace: (a) výroční zprávy, (b) inspekční zprávy, (c) školní vzdělávací programy, (d) školní časopis, (e) www stránky školy. Smíšená metodologie opírající se o četné metody, různorodé zdroje a týmový přístup umožnila validaci dat. Parametry šetření dokumentuje tabulka 1.

Tabulka 1

Výzkumná data, použité metody, jejich rozsah a frekvence

\begin{tabular}{lcccc}
\hline ZŠ / sbor: & Sibiřská & Žulová & Rekordní & Železná \\
\hline Termín šetření (měsíc/rok) & $\mathrm{V} / 2017$ & $\mathrm{~V} / 2017$ & $\mathrm{IX} / 2017$ & $\mathrm{XI} / 2017$ \\
\hline Doba terénního šetření (počet dnů) & 2 & 2 & 2 & 2 \\
\hline Počet výzkumníků & 3 & 3 & 3 & 3 \\
\hline Použité metody: & & & & \\
\hline (1) Hloubkový polostrukturovaný rozhovor & 6 & 7 & 10 & 9 \\
\hline (2) Dotazník pro ředitele/ředitelku (2016) & 1 & 1 & 1 & 1 \\
\hline (3) Skupinový rozhovor (šestice žáků) & 1 & 1 & 1 & 1 \\
\hline (4) Strukturované pozorování výuky & 5 & 3 & 6 & 6 \\
\hline (5) Zúčastněné pozorování (provozní porada) & 1 & 1 & 1 & 1 \\
\hline (6) Nestrukturované pozorování & ano & ano & ano & ano \\
\hline (7) Analýza školní a žákovské dokumentace & a, c, e & a, c, e & a, c, d, e & a, b, c, d, e \\
\hline
\end{tabular}

Legenda: a) výroční zpráva; b) inspekční zpráva; c) ŠVP; d) školní časopis; e) www stránky

7 Dotazník byl distribuován v první fázi výzkumu v roce 2016 společně s dotazníkem OCDQ-RS. 
Legenda: a) výroční zpráva; b) inspekční zpráva; c) ŠVP; d) školní časopis; e) www stránky Individuální i skupinové rozhovory byly nahrávány, z audionahrávek byly pořízeny přepisy. Všechny terénní vstupy byly $v$ týmech bezprostředně diskutovány a pořizovány byly také primární glosované zprávy z terénu. Vytvořené transkripce obsahu rozhovorů byly „ručně“ (papír-tužka) analyzovány otevřeným kódováním, kategorizovány (Švaříček \& Šed’ová et al., 2007, s. 211-222) a z terénních poznámek editorovány (Miovský, 2006, s. 211). Obsahové analýze, následné kategorizaci, interpretaci a editaci byly podrobeny také obsahy pozorovacích archů a školní dokumentace. Při vytěžování dat tedy nešlo, jak v souvislosti s vžitým názvem metody upozorňuje Gavora (2015, s. 350), jen o jejich analýzu, ale i o další s analýzou spojené procesy. Následně došlo ke konfrontaci výsledných dat mezi vybranými dvojicemi sborů.

\subsection{Výběr učitelských sborů a jejich „evidentní znaky“}

V souladu s cílem našeho výzkumu byl proveden záměrný výběr čtyř (dvou dvojic) učitelských sborů ze souboru statistického výběru kvantitativně šetřených sborů ZŠ (N = 125). Kritériem výběru byla výrazná odlišnost, resp. blízká podobnost dvou zjištěných charakteristik sociálního klimatu (IO, grafický profil). Současně ale výběr přihlížel i k tomu, aby u obou dvojic byly vždy srovnatelné relevantní vnější charakteristiky sborů, resp. škol (zejména velikost, lokalizace škol, délka působení managementu aj.). Výběr sborů byl do jisté míry limitován výzkumnými možnostmi terénu (možný průnik do školy a ochota vedení akceptovat požadavky kvalitativních procedur výzkumu bez omezení). Zkoumaným učitelským sborům, resp. školám, jsme z důvodu anonymizace přisoudili symbolizované názvy (Sibiřská, Žulová, Rekordní, Železná).

První dvojice učitelských sborů byla vybrána jako dva protipóly extrémních případů. Jak uvádí Gavora (2010, s. 184), v kvalitativním výzkumu jde o jeden z možných zpo̊sobů výběru, přičemž extrémní případ může nabývat kladné i záporné polohy. Jiní autoři hovoří v tomto smyslu např. o „maximálně variantních typech případů“ (Švaříček \& Šed’ová et al. 2007, s. 74-75) nebo o „výběru s maximální variací“ (Hendl, 2005, s. 154) apod. Vždy jde o postihnutí krajních hodnot sledovaného fenoménu, které vymezují jeho interval, resp. rámec. Protikladně vybrané případy implikují v kvalitativním výzkumu komparativní postupy až do analytických a interpretačních fází metodami kontrastu a srovnávání (Miovský, 2006, s. 223). 
Sledovaným kontrastem jsou v našem šetření extrémně odlišné hodnoty sociálního klimatu první dvojice učitelských sborů. Základní školy, ve kterých byly identifikovány učitelské sbory s krajními hodnotami sociálního klimatu, jsme nazvali Sibiřská (s excelentními hodnotami) a Žulová (s extrémně nepř́íznivými hodnotami). Naopak obdobné charakteristiky oba sbory vykazovaly co do velikosti, typu venkovského sídla školy a doby působení managementu školy. Tabulka 2 prezentuje dílčí dimenze a celkový index otevřenosti (IO) sociálního klimatu vybrané dvojice učitelských sborů. Uvedeny jsou rozdíly klimatu mezi sbory a průměrné republikové hodnoty. ${ }^{8}$ Dva grafy (obrázek 1 ) ilustrují redukovanými hodnotami inverzní grafické profily klimatu celých sborů a subsborů prvního a druhého stupně na obou školách.

Tabulka 2

Charakteristiky sociálního klimatu učitelských sborů ZŠ Sibiřská a ZŠ Žulová

\begin{tabular}{lcccccccc}
\hline Sbor ZŠ (2016) & PU & Poř. & SUP & DIR & ANG & FRUS & INT & IO \\
\hline Sibiřská & 9 & 1. & 24,67 & 14,94 & 32,50 & 8,56 & 10,00 & 33,67 \\
Žulová & 10 & 124. & 17,10 & 22,60 & 24,50 & 14,40 & 7,50 & 4,60 \\
Rozdíly & -1 & -123 & 7,57 & $-7,66$ & 8,00 & $-5,84$ & 2,50 & 29,07 \\
Průměr ČR (N = 125) & $\mathrm{x}$ & $\mathrm{x}$ & 20,77 & 17,35 & 27,79 & 11,14 & 8,98 & 20,08 \\
\hline
\end{tabular}

PU = počet učitelů v učitelském sboru školy, kteří vyplnili dotazník OCDQ-RS
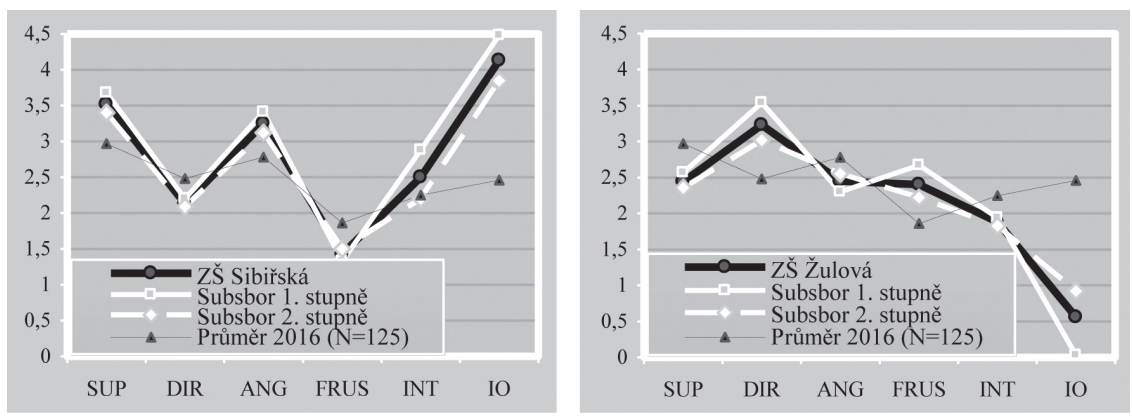

Obrázek 1. Grafické profily sociálního klimatu učitelských sborů ZŠ Sibiřská a ZŠ Žulová.

\footnotetext{
8 Aritmetický průměr hodnot sociálního klimatu všech šetřených učitelských sborů $(\mathrm{N}=125$; statistický stratifikovaný výběr) v rámci České republiky je přirozeně jen teoretickým konstruktem, který relativizuje data z jednotlivých sborů.
} 
Učitelské sbory ZŠ Sibiřské a ZŠ Žulové, jak dokládají tabelovaná data i grafické profily, se vzájemně zásadně odlišují charakteristikami sociálního klimatu. Jednak pořadím (mezi 125 sbory základních škol figurovala Sibiřská na prvním a Žulová na 124. místě), resp. hodnotami IO, a dále hodnotami dílčích dimenzí klimatu. Grafické profily klimatu sborů představují vzájemně přibližně inverzní charakteristiky (obrázek 1). Sbor ZŠ Sibiřské vykazuje excelentní parametry klimatu, sbor ZŠ Žulové naopak extrémně nepříznivé. ${ }^{9}$ Zjevný rozdíl mezi oběma relativně malými učitelskými sbory je v podílu mužů. V Sibiřské představují muži téměř polovinu učitelského sboru (46,2%), Žulová má sbor složený pouze z žen.

Záměrem výběru ale bylo zachovat podobnost některých významných znaků, u kterých lze předpokládat vliv na uspořádání a kvalitu učitelského sboru. Obě školy jsou velikostně stejné kategorie (devítitřídní, podobný je počet učitelů) a obě sídlí v menších obcích, kde je pouze jediná základní škola. Nicméně ZŠ Sibiřská (160 žáků, v průměru 17,7 žáka na jednu třídu) se nachází v typicky spádové zemědělské obci (městys); ZŠ Žulová (210 žáků, v průměru 23,3 na třídu) je situována v samostatné obci s průmyslovou tradicí a sídlící na periferii velkého města. $V$ obou školách jsou ve vedení ženy (včetně zástupkyň) a obě ředitelky řídí školu shodně pět let.

Druhá dvojice učitelských sborů reprezentuje z hlediska sociálního klimatu a současně i dalších evidentních znaků dva velmi podobné př́pady („dvojčata"). Sociální klima učitelských sborů ZŠ Rekordní a ZŠ Železné náleží k excelentním a svými parametry (tab. 3), včetně grafických profilů (obrázek 2), si jsou v zásadě velmi podobné. Přesto charakteristiky jejich klimatu vykazují i některé méně významné rozdíly, např. pořadí ve výběrovém souboru (Rekordní 2.; Železná 16.), v hodnotách celkového indexu otevřenosti (IO) nebo částečně i v dílčích dimenzích, zejména $\mathrm{v}$ dimenzi direktivity (DIR). ${ }^{10}$

9 Kromě vysokých hodnot celkového indexu otevřenosti (IO) se př́znivé charakteristiky sociálního klimatu učitelského sboru vyznačují nadprůměrnými hodnotami suportivity (SUP) a angažovanosti (ANG), současně podprůměrnými hodnotami direktivity (DIR) a frustrace (FRUS) a zpravidla nízkou variabilitou výpovědí celého sboru (konzistentností). U nepř́íznivých charakteristik klimatu je tomu naopak. Zároveň je významná i vzájemná konstelace dílčích dimenzí, vyjadřovaná grafickým profilem. Pro příznivé klima je typický tvar dvojitého písmene „W“; pro nepříznivé klima (inverzní) podoba písmene „M“.

10 Problematická ochota některých škol, resp. jejich malá vstř́́cnost ke kvalitativnímu šetření, a naše snaha zachovat shodné (nebo alespoň podobné) vnější charakteristiky sborů a škol se negativně projevilo u „sestavování“ dvojice učitelských sborů Železná a Rekordní, u kterých tak lze v určitém rozporu s principem výběru shledat v charakteristikách klimatu i znatelnější rozdíly. 
Ukázalo se, že nalézt při zachování relevantních znaků dvojici shodných sborů je obtížnější než „,spárovat“ dva sbory diametrálně odlišné. Vzhledem k výzkumnému cíli doplňuje výběr „dvojčat" dvojici protikladných sborů ve smyslu komplementárním i kontrolním.

Při výběru „dvojčat“ byla upřednostněna přibližná shoda velikosti obou škol, jejich lokalizace a délka působení ředitele. Obě školy jsou osmnáctitřídní; v ZŠ Rekordní je 480 žáků a 26 učitelů, v Železné 500 žáků a 28 učitelů, z toho v obou sborech 6 mužů (podíl mužů 23,1\% a 21,4\% odpovídá hodnotám celostátnímu průměru). Sídla obou škol se nacházejí v bývalých okresních městech (počet obyvatel je v sídle Železné o 6 tis. vyšší), v nichž existují shodně ještě další tři ZŠ. Oba ředitelé jsou muži a řídí školu významně dlouhou dobu (26 a 18 let); v obou školách jsou zástupkyněmi ženy.

Tabulka 3

Charakteristiky sociálního klimatu učitelských sborů ZŠ Železná a ZŠ Rekordní

\begin{tabular}{lllllllll}
\hline Sbor ZŠ (2016) & PU & Poř. & SUP & DIR & ANG & FRUS & INT & IO \\
\hline Železná & 26 & 16. & 22,77 & 18,96 & 32,81 & 9,96 & 10,23 & 26,65 \\
\hline Rekordní & 28 & 2. & 25,29 & 15,73 & 32,36 & 8,50 & 10,02 & $\frac{33,41}{-6,76}$ \\
\hline Rozdíly: & -2 & 14 & $-2,52$ & 3,23 & 0,45 & 1,46 & 0,21 & $\frac{-6,76}{20,08}$ \\
\hline Průměr ČR (N=125) & $\mathrm{x}$ & $\mathrm{x}$ & 20,77 & 17,35 & 27,79 & 11,14 & 8,98 & \\
\hline
\end{tabular}

$\mathrm{PU}=$ počet učitelů v učitelském sboru školy, kteří vyplnili dotazník OCDQ-RS
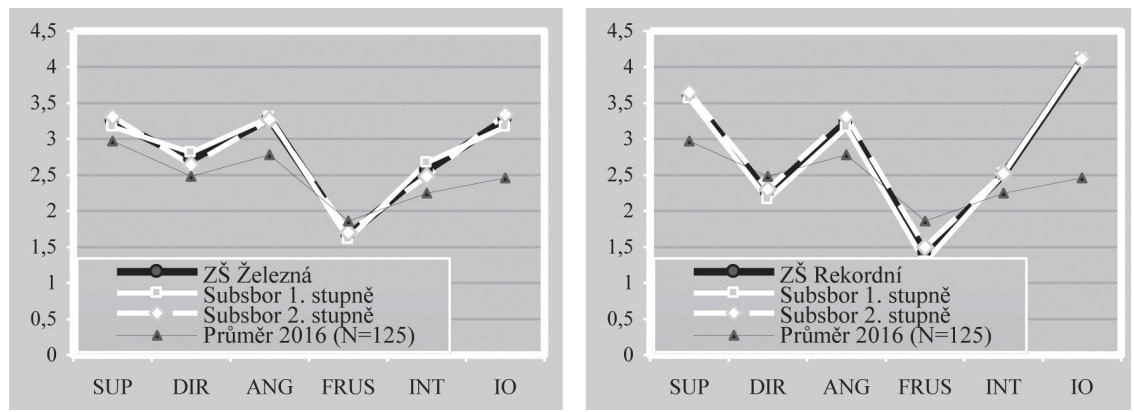

Obrázek 2. Grafické profily sociálního klimatu učitelských sborů ZŠ Železná a ZŠ Rekordní. 


\section{$3 \quad$ Výsledky kvalitativní analýzy}

Kvalitativní analýze byly podrobeny dvě vybrané dvojice učitelských sborů. Účelem byla identifikace význačných atributů jejich fungování, souvisejících se specifickým profilem sociálního klimatu každého vybraného sboru. V následujících dvou oddílech předkládáme výsledky analýzy obou dvojic škol.

\subsection{Sbory - „protipóly“: dvojice učitelských sborů s krajně odlišnými hodnotami sociálního klimatu}

ZŠ Sibiřská a ZŠ Žulová představují dvojici škol s extrémně odlišnými hodnotami sociálního klimatu učitelského sboru, a to navzdory tomu, že jde v obou př́padech o malé školy „rodinného typu“. Analýza zde odhalila význačné rozdíly v klíčových atributech fungování obou sborů.

\section{Sdílení vize rozvoje a fungování školy}

Jednu z hlavních př́íčin extrémní odlišnosti klimatu učitelských sborů těchto dvou škol spatřujeme v rozdílném sdílení vize ${ }^{11}$ rozvoje a fungování školy: hlavním krédem první z dvojice škol (ZŠ Sibiřská) je otevřená „škola rodinného typu" s důrazem na důvěru, vzájemný respekt a spolupráci mezi všemi zúčastněnými - vedením školy, učiteli, žáky i rodiči. Za základní pilír této koncepce rozvoje školy považuje ředitelka personální stabilitu učitelského sboru. Prioritou školy je otevřenost v jednání, podpora práce učitelů a individuální př́ístup ke každému žákovi. ${ }^{12}$

Tyto ideje otevřenosti a vstřícnosti směřují ke všem aktérům školy a jsou patrné z mnoha „detailů“ v jejím životě. Například třídy 1. a 2. stupně jsou cíleně umístěny na stejných patrech, dveře do ředitelny jsou stále otevřené, pro žáky dojíždějící z méně dostupných míst zajistilo vedení školy ve spolupráci s obecním úřadem „školní automobil“. Zjevné je také to, že jde o ideje

11 Vizi, ve shodě s Polem a kol. (2003, s. 87), chápeme jako „živou představu cílového či žádoucího stavu“.

12 „Vstoupili jsme do ředitelny, malé pracovně vyhlížející místnosti s množstvím administrativního materiálu, žákovských sešitů i pomůcek pro matematiku. Paní ředitelka nás velmi mile přivítala a po našem souhlasu, že bychom s ní vypili kávu, se začala shánět po hrnečcích. Překvapilo nás, ale současně dojalo, jak dlouho je sháněla. Výsledkem jejího snažení nebyly výstavní kusy porcelánu, tak jak bývá ve většině ředitelen zvykem (automat na kávu nebyl v ředitelně, ale v přilehlé sborovně). Ani nábytek nebyl v ředitelně reprezentativní... Až později mi tato situace i s dalšími indiciemi dokonale doplnila obraz, v čem jsou priority ředitelky ZŠ Sibiřské - v učitelích a v žácích, nikoliv ve spektakulární reprezentativnosti vlastní ředitelny." (z terénních poznámek výzkumníků v ZŠ Sibiřská). 
společné, ředitelce se podařilo pro ně učitele získat, jsou tedy učiteli akceptovány a společně rozvíjeny, zároveň jsou pozitivně hodnocené a sdílené i žáky a jejich rodiči. Vztahy mezi rodiči a učiteli jsou často přátelské i na neformální úrovni. Výborné vztahy vyplývají mimo jiné z toho, že bývalí žáci (ač nejsou vždy místní) přivádějí do školy své děti. Škola se zároveň těší dlouholeté podpoře zřizovatele, tj. obecního úřadu.

Druhá škola (ZŠ Žulová) deklaruje vizi být atraktivní školou se zajímavými formami vzdělávání. Nové vedení chtělo zvýšit dosavadní malou aktivitu školy ve vztahu k žákům, k rodičům a veřejnosti. Pravděpodobně ale stavělo od počátku svého působení také na snaze vyhovět požadavkům zřizovatele, jenž do vedení školy vkládal vysoká očekávání. Důraz je tudíž kladen zejména na viditelné, až spektakulární znaky kvality školy - na zapojování školy do mnoha akcí a projektů, na akce pro rodiče a veřejnost. $V$ úvodu webových stránek se škola prezentuje fotografiemi počítačové učebny a interaktivní výuky. Výroční zpráva 2017/2018 deklaruje jako koncepční záměr, že bude vytvořeno atraktivní školní prostředí se zajímavou formou vzdělávání a výchovy a že škola nabízí četné volnočasové aktivity. Snahou vedení ZŠ Žulová tedy je vytvářet image výborně fungující, akční a rodičům otevřené školy.

Ředitelce se však nepodařilo svou vizi sboru jasně předložit a přesvědčit jej o ní. Její pozornost byla navíc od počátku zaměřena spíše ke každodenní operativě, řízení práce učitelek a zavádění dílčích změn, v nichž však vize rozvoje školy prakticky nenabyla konkrétní podoby. Většina učitelek se s ředitelčiným pojetím směřování školy neztotožňuje a nesdílí je. Z rozhovorů s učitelkami i s ředitelkou vyplývá, že s ředitelčinou koncepcí školy nejsou učitelky prakticky ani seznamovány a už vůbec nejsou do jejího vytváření zapojovány. V rozhovorech uváděla ředitelka opakovaně, že koncepci školy diskutovaly a vytvářely pouze se zástupkyní: „My s paní zástupkyní jsme rozhodly..... Učitelky by patrně nebyly přímo $v$ rozporu s představami vedení, ale chybí jim objasňování smyslu a širšího kontextu zaváděných opatření, možnost o opatřeních diskutovat a spolurozhodovat.

Geneze a styl vedení

V porovnávané dvojici škol shledáváme zásadní rozdíly v genezi a stylu vedení:

Do ZŠ Sibiřská přišla ředitelka „Zvenči“ a po neúspěšném oslovení bývalého zástupce si ponechala celý rok na to, aby si posléze přivedla zástupkyni, také 
odjinud. Ředitelka vstoupila do školy, kde byla poměrně vysoká spokojenost $\mathrm{v}$ učitelském sboru, nicméně z pohledu ředitelky to byla spokojenost postavená na poměrně malých požadavcích na učitele. Snahou ředitelky tedy bylo navázat na dobré dosavadní fungování školy i učitelského kolektivu, ale zároveň aktivizovat sbor k vyšší angažovanosti, a tím dosáhnout vyšší kvality výchovně-vzdělávacího procesu ve škole.

V ZŠ Žulová jsou ředitelka i zástupkyně insideři - obě byly řadu let jako učitelky součástí učitelského kolektivu. Hlavní motivací nového vedení k vstupu do této funkce byla podle slov paní ředitelky nespokojenost s dosavadním fungováním školy - ředitelka i její zástupkyně chtěly zcela změnit poměry, s nimiž byly při minulém vedení nespokojeny: byly přesvědčeny, že se učitelé této školy málo zapojují a že škola nevyvíjí dost aktivity ve vztahu k veřejnosti. Sboru však nízké nároky minulé ředitelky vyhovovaly, navíc nově jmenované vedení nemělo u učitelského sboru patřičnou autoritu, ve sboru byly do té doby spíše méně uznávanými a podceňovanými členkami. Zřejmě také nebyly vybaveny potřebnými manažerskými předpoklady a od počátku se jim nedařilo získat sbor pro svou vizi a přesvědčit učitele o nutnosti zvýšení pracovního nasazení, v jednání s učiteli se dopouštěly chyb. Styl vedení nebyl adekvátní podmínkám a personální situaci.

Demokratický, na lidi orientovaný styl vedení v ZŠ Sibiřská a manažeristický styl vedení (Pol, 2007, s. 34-35) v ZŠ Žulová jsou výraznými, zásadně odlišnými znaky této dvojice škol. ${ }^{13}$

Složení učitelského sboru v ZŠ Sibiřská je výsledkem cílevědomého působení ředitelky školy. $V$ počátcích svého působení dala zelenou odchodu některých zaměstnanců, kteří se neztotožňovali s pojetím nového vedení. Ostatní učitele se jí podařilo získat ke spolupráci při realizaci její vize rozvoje školy. Nadále si nové učitele velmi pečlivě vybírá, a to i za cenu, že se po delší dobu nedaří získat učitele určité konkrétní aprobace. Jak se sama vyjádřila, prioritní pro ni není aprobace, ale osobnostní stránka, pracovní zapojení, komunikace, pozitivní vztah $\mathrm{k}$ dětem. Ve třináctičlenném týmu učitelského sboru působí pět mužů. Na kvalitu pedagogické činnosti učitelů má ředitelka vysoké nároky.

13 Pol (2007, s. 34-35) vymezuje pojem „manažerismus“ jako krajní formu manažerského stylu, vyznačující se přehnanou snahou o efektivitu a o kontrolu učitelů, mimo jiné i rozšířením povinné administrativy. O stylech řízení (manažerský, demokratický na lidi orientovaný, transformativní aj.) více např. Rozkovcová a Novotová (2018), Bush a Glover (2014), Kirkbride (2006) nebo Harris a Chapman (2002). 
V počátcích svého působení musela učitele přesvědčit o své vizi a motivovat je k vyššímu pracovnímu nasazení, než byli doposud zvyklí. Učitelský sbor hodnotí ředitelka jako dobrý tým, vztahy v něm označila jako „většinou dobré, kolegiální, spolupracující, pomáhající, bez intrik“. Přednosti sboru vidí v týmové spolupráci, sdílení společné vize školy, uvědomělém dodržování nastavených pravidel a vstřícném přístupu k žákům. Naproti tomu slabá místa a př́ípadná rizika shledává pouze $v$ dílčích dovednostech a případné menší ochotě ke změnám u některých učitelů (např. ve vztahu k ICT). Věkové složení vnímá ředitelka Sibiřské jako vyvážené a vidí potenciál pro rozvoj školy ve všech věkových skupinách: „o cílené zásahy z hlediska věku se nesnažím“.

Učitelský sbor ZŠ Žulová je výhradně ženský. Ředitelka prakticky vůbec nevidí a nepřijímá sbor jako tým, nezajímá ji souhra a spolupráce, přednosti vidí v poslušnosti a plnění úkolů: „předměty, které učí, učí většinou rádi, práci, ke které jsou přivedeni, vykonávají poctivě“. Plnění úkolů a dodržování požadavků soustavně kontroluje, důraz klade na nutnost vše dokumentovat, což učitelům výrazně navyšuje administrativní zátěž. Ve výpovědích ředitelky nebyly identifikovány již žádné další přednosti sboru, naopak, na straně učitelů bylo uváděno mnoho nedostatků: „těžce přijímají změnu, staví se k povinné administrativě negativně, doporučení z hospitací často neberou v potaz“. Potenciál sboru vidí ředitelka v „mladších a nově přijatých učitelkách s chutí pracovat s dětmi i mimo dopolední výuku, s novými nápady pro činnosti školy, s chutí se dále vzdělávat“. Za „nové nápady“ je však reálně brána projevovaná iniciativa při realizaci akcí naplánovaných ředitelkou. Sbor ředitelka rozděluje na mladší, ochotné pracovat, a starší - nad 50 let, s neochotou ke změnám: „Pokoušíme se o částečné omlazení, do 50 let mají učitelé větší chut' pracovat, vstřícnější prrístup k dětem, větší nadhled a nebrání se změnám."

Zatímco v ZŠ Sibiřská vidí ředitelka stabilizující faktor pro fungování učitelského sboru v jasné koncepci školy, v možnosti podílet se na spolurozhodování a řízení školy a v personální stabilitě, na ZŠ Žulová je podle ředitelky stabilizujícím faktorem „usměrňování postojů a přístupů některých učitelů“.

V ZŠ Sibiřská je týmová spolupráce celého učitelského sboru spolu s vedením (a také s nepedagogickými pracovníky školy) základním pilířem dobrého fungování školy. V ZŠ Žulová platí „my“ a „ony“. „My pilné, snažící se, angažované a nepochopené“ a „ony líné, stagnující, nepřijímající nic nového (ani nové snaživé kolegyně) a nechápající naše snahy“. Slovy zástupkyně: 
Přijde mi, že oni si tam ty problémy trošku jako tvoří sami - něco se jim řekne, nějakým způsobem se má postupovat, a oni nejsou moc jako... nevim, ochotné nebo... jakoby... všechno tam tak jako rozebírají, převrtávají, přetáčí... Já si myslím, jo, přetáčejí a všechno chtějí, aby bylo jako po nich.

Výrazně odlišnými znaky vztahu vedení k učitelskému sboru jsou tedy důvěra k učitelům a pozitivní vnímání jejich profesionality a sboru jako týmu v ZŠ Sibiřská oproti nedůvěře, podceňování a zvýšené snaze kontrolovat práci učitelů, spojené $\mathrm{s}$ nedostatkem podpory týmové spolupráce $\mathrm{v}$ učitelském sboru v ZŠ Žulová.

\section{Mezilidské vztahy a komunikace}

Uvnitř sborů ZŠ Sibiřská a ZŠ Žulová jsou patrné výrazné rozdíly v hodnocení vztahů. V obou školách hodnotí učitelé vztahy uvnitř sboru jako kolegiální. Zatímco v ZŠ Sibiřská je ale možno hovořit o sounáležitosti celého sboru, v ZŠ Žulová se vytvořilo několik skupin.

V ZŠ Sibiřská mají učitelé společnou sborovnu v blízkosti ředitelny, v níž se scházejí o přestávkách a po výuce. Ve shodě se Švaříčkem (2009, s. 95), který sborovnu chápe jako prostor otevřené kritiky, se učitelé v Sibiřské vyjadřují, že společná sborovna podporuje otevřenou komunikaci a sdílení informací (i s ředitelkou, která také často tráví přestávky ve sborovně). Nedorozumění a problémy se řeší hned v zárodku, učitelé vzájemně konzultují případné problémy se žáky. Dostatek prostoru zbývá i na nepracovní témata a sdílení radostí i starostí ze soukromého života. Někteří učitelé se vyjádřili i o menším soukromí, které mají při absenci kabinetů, avšak výhody společné sborovny i oni považují za převažující. Kolektiv učitelů se sám hodnotí jako kolegiální, spolupracující, přátelský. I žáci, s nimiž jsme vedli rozhovor, hodnotí učitelský sbor jako fungující celek, vnímají otevřenou a kolegiální komunikaci mezi učiteli, žádného učitele by nevyměnili a žádného nepovažují za narušujícího jednotu učitelského týmu.

Většina učitelů kladně hodnotí rodinný ráz školy. Rodiče současných žáků byli většinou dříve žáky této školy. Roli hraje i venkovský ráz sídla školy, kde se prakticky všichni znají (i přes výraznou spádovost). Z toho vyplývají i užší vazby, otevřené sociální vztahy. Učitelé znají rodinná zázemí svých žáků a přistupují k nim individuálně, což umožňuje i nižší počet žáků ve třídách. Příznačné je, že cca $60 \%$ žáků a téměř všichni učitelé nejsou místní, ale dojíždějí z okolních obcí nejen spádové oblasti. Rodinný ráz školy tedy není dán 
tím, že by všichni byli „sousedy“ v obci, naopak, ze strany žáků i učitelů jde o záměrný výběr a sounáležitost se školou.

V ZŠ Žulová je obtížnější situace daná skutečností, že škola je umístěna ve dvou budovách, což přispívá i k výrazné separaci sborů 1. a 2. stupně. Učitelské kolektivy tedy fungují jako dva oddělené celky, které se scházejí pouze na společné porady, školení a akce školy. Oba početně malé kolektivy hodnotí vztahy jako dobré, kolegiální. Jedna z učitelek 2 . stupně k tomu řekla: „U nás ve sborovně, když se zavřou dveře, tak tam je úplně úžasný klima." Učitelky působící na škole déle vnímají jednotu v původním sboru: „Je to fakt, že taková ta stará banda, co tady byla ještě za předchozího vedení, tak ty se za ty léta semkli nějakým způsobem a spolupracujou...., avšak s nově příchozími se obtížněji sžívají a hodnotí jednání některých z nich jako „kariérismus". Na prvním stupni cítí učitelky jako velmi rušivý element každodenní návštěvy (kontroly) paní zástupkyně. Žáci se ve skupinovém rozhovoru nevyjadřovali ke vztahům mezi učitelkami jednoznačně. Někteří oceňují rodinnou atmosféru školy a hodnotí vztahy mezi učitelkami jako dobré. Jiní ale shledávali ve vzájemném jednání učitelek určitý nesoulad a nepohodu, vztahy k žákům vnímali u jednotlivých učitelek odlišně. Ve sboru se shodli pouze na jedné paní učitelce, která s nimi dokáže dobře komunikovat, je př́ímá a se žáky jedná přívětivě. Na ostatní učitelky se názory žáků dosti různily, ale z výpovědí vyznívalo, že se žákům často stává, že se k nim učitelky chovají odměřeně a méně př́ijemně, o některých se žáci vyjadřovali, že jim na žácích nezáleží a že je asi „nemají rády“: No, někteří učitelé už třeba přijdou k nám takový nepř́jemný do třídy, že jo, my jsme jim třeba nic neudělali, ale oni už jsou takový nepř́ijemný na nás kvůli ničemu..." Zde se nabízí otázka, zda určitá „otrávenost“ a neochota, kterou žáci ze strany učitelek pocit’ují, je jednou z př́čin horšího klimatu učitelského sboru, či zda jde o důsledek učitelkami pocitované frustrace a malé podpory ze strany vedení. Přesto ale výsledky šetření klimatu sboru ukazují, že distribuce dimenze angažovanosti je přiměřeně vázána i na práci s žáky.

Z roztř́šstěnosti učitelského sboru v ZŠ Žulová plyne také ztížená komunikace uvnitř sboru, která je zároveň znesnadněná i prostorově - existencí dvou oddělených pracovišt'. Učitelky zároveň pocit’ují váznoucí komunikaci směrem od vedení, často probíhá podle slov učitelek pouze prostřednictvím e-mailu, z čehož pak plynou omyly a „chyby“, jichž se učitelky dopouštějí z nedorozumění. Problém v transferu informací, neujasněná pravidla a problematická komunikace se ukazují v této škole jako jeden $\mathrm{z}$ faktorů vysoké frustrace uvnitř učitelského sboru. 


\section{Angažovanost a iniciativa učitelů}

V obou školách se učitelé hodnotí jako aktivní, „pracující naplno“. Odlišné je však vnímání podstaty této pracovní aktivity. V ZŠ Sibiřská se učitelé cítí (a vzájemně se hodnotí) jako angažovaní, participující na vzdělávání a výchově žáků a na celkové kultuře školy, v ZŠ Žulová se vidí jako plně zapojení, iniciativní ve smyslu pracovního nasazení na všech akcích školy a plnění úkolů, avšak postrádají možnost angažovat se v rozhodování o směřování školy.

Na rozdíl od ředitelky jsou učitelky na ZŠ Žulová přesvědčeny, že pracují naplno, vykonávají vše, co se od nich očekává, i když dlouhodobě cítí vysokou zátěž:

Většinu projektů vybírá vedení. A přijde s tím jako s jasnou věcí. A asi většinou se k tomu nemůžeme vyjádřit, jestli chceme, nebo nechceme. Prostě, jak se objeví nějaká akce, tak se snažíme do toho zapojit a myslím si, že už je toho hrozně moc... Jako většinou my tím, že je tady ta stará garda, tak to vezmem a táhneme prostě, no, nandáme to na sebe... Ale už je to takový, jako že... aby se nám nerozjely nohy za chvilku, jak máme naložený záda.

Zúčastněné pozorování na provozní poradě školy uvedenou výpověd' potvrzuje. Učitelé jsou pověřováni organizací nadměrného množství mimoškolních aktivit.

Vysoká míra pocitované zátěže učitelek na ZŠ Žulová je dána nejen soustavně rostoucím množstvím projektů a akcí, do nichž jsou učitelky z rozhodnutí vedení školy zapojovány, ale také kritickým postojem vedení ke kvalitě pedagogické práce a nedůvěrou k pedagogickým a didaktickým kompetencím učitelek. Práce učitelek je nadmíru kontrolována (mj. častými neohlášenými hospitacemi s následnými pohovory, které jsou někdy reakcí na „stížnosti“ žáků na učitele na Facebooku; ředitelka jim popřává sluchu, aniž by ji zajímal pohled učitelek). Učitelky také zatěžuje nadměrná administrativa s tím spojená. Důsledkem frustrace učitelek může být následně i jejich menší snaha přicházet s vlastními podněty ovlivňujícími život školy.

\subsection{Sbory - „dvojčata“: dvojice učitelských sborů s velmi podobnými a zároveň excelentními hodnotami sociálního klimatu}

Učitelské sbory ZŠ Rekordní a ZŠ Železná se vyznačují velmi podobnými, v obou př́padech excelentními hodnotami sociálního klimatu učitelského sboru. Bylo by tedy možno očekávat i podobné charakteristiky těchto sborů. 
Přesto byly vedle shodných či podobných znaků odhaleny v podmínkách fungování obou učitelských sborů i výrazné rozdíly.

\section{Sdílení vize rozvoje a fungování školy}

Společným znakem obou škol jsou efektivní způsoby sdílení společných cílů a hodnot mezi vedením a učitelským sborem, participace učitelů na řízení školy, a tomu odpovídající angažovanost učitelů ve věcech fungování školy a školního života. Jádrem vize směřování obou škol je kvalitní vzdělávání žáků a otevřené, podporující prostředí, partnerské vztahy mezi učiteli a žáky a mezi školou a rodiči. V ZŠ Železná je ředitel ve své funkci od počátku existence školy, její obraz tudíž tvořil od základu. Vize školy, jejímž hlavním nositelem ředitel je, má pro fungování školy zásadní význam. Od počátku svého působení usiloval ředitel o promyšlené zavádění netradičních, inovativních přístupů a o otevřenost školy všem dětem. Škola má ve městě vysokou prestiž. Z rozhovorů s učiteli i ředitelem vyplynulo, že učitelský sbor je formován podle společné vize školy a učitelé, kteří se s vizí neztotožnili, odcházejí jinam. Jak uvedl ředitel na otázku slabších míst učitelského sboru: „velmi obtížné zařazení a zapracování nových učitelů, především čerstvých absolventů, kteří nejsou na naše způsoby práce a celkové nasazení připraveni“.

V ZŠ Rekordní přišel ředitel do již fungující vzdělávací instituce z pozice zástupce ředitele jiné školy, a ač učitelům nebyl před svým příchodem znám, předcházela jej pověst oblíbeného, vstřícného a vlídného vedoucího pracovníka. Do školy vnesl vizi kvalitně fungující školy poskytující žákům optimální podmínky k učení, učitelům kolegiální vztahy ve sboru. Základem je přátelská atmosféra založená na vzájemné důvěře. Součástí tohoto pojetí je vysoká míra otevřenosti $\mathrm{k}$ iniciativě a námětům učitelů. $\mathrm{V}$ současné době má škola ve městě pověst školy s vysokými nároky na žáky a zároveň poskytující kvalitní vzdělání. Škola dlouhodobě zaznamenává ze strany rodičovské veřejnosti převis poptávky, kterou není možno zcela uspokojit.

\section{Styl vedení a podpora angažovanosti učitelů}

Jádro stylu vedení v obou školách je možno vidět v orientaci na lidi a na partnerské vztahy mezi nimi. Přesto lze ve způsobu realizace tohoto demokratického stylu vedení (zejména v rovině prosazování ředitelovy koncepce fungování a směřování školy) postihnout zřejmé rozdíly. 
Vedení ZŠ Rekordní lze charakterizovat jako nedirektivní. Klíčovým fenoménem fungování školy je vysoká důvěra mezi všemi aktéry. Důvěra ředitele k učitelům a učitelů k řediteli v Rekordní je vzájemná, řešení problémů a rozhodnutí ve věcech fungování školy jsou výsledkem společného konsenzu vedení a učitelů. Tuto skutečnost vyjádřil ředitel v dotazníku, kde na otázku, co je podle něj stabilizujícím faktorem pro fungování učitelského sboru, odpověděl: „důvěra a podpora ze strany vedení školy“. Učitelé přicházejí s návrhy, které ředitel koriguje a schvaluje. Důvěra k učitelům se projevuje velkou mírou volnosti v práci a rozhodování a v nenásilné kontrole práce učitelů. Učitelka prvního stupně s 37letou praxí k tomu ř́ká: „Tady je to opravdu takový jako blízký... To vedení se snaží vyjít maximálně vstříc." Podle ředitele i učitelů je tato důvěra vzájemná. ${ }^{14}$ Ředitel uvedl: „,... Do práce nechodí nikdo se strachem." Učitelé se cítí svobodní a svým způsobem zavázáni ke kvalitní práci a vysokým výkonům. $Z$ výpovědí $v$ rozhovorech vyznívá, že by si učitelé nedovolili dělat svou práci špatně. Někteří učitelé se přímo vyjádřili, že pocitují zodpovědnost vůči vedení školy a vůči velmi dobrému jménu školy, které nechtějí pokazit.

Styl vedení ředitele v ZŠ Železná je př́́kladem transformativního a na lidi orientovaného vedení s pevně prosazovanou vizí (Rozkovcová \& Novotová, 2018). Jednání ředitele je přímé a důsledné. Ředitel chápe školu jako službu rodičům a dětem, přičemž služba neznamená podbízení se rodičům a slevování z požadavků. Naopak, vysoká úroveň vzdělávání, která je ve škole prioritou, předpokládá (a vyžaduje) kvalitní práci učitelů i žáků a kvalitní spolupráci školy a rodiny. Své pojetí tedy prosazuje pevně jak v učitelském sboru, tak ve vztahu k rodičům. Od učitelů vyžaduje, aby se v práci věnovali plně svým žákům. Zakládá si na tom, aby mezi učiteli a žáky byl partnerský vztah. Na otázku, co je pro něj stabilizujícím faktorem fungování učitelského sboru, odpovídá: „Jasná vize a filosofie školy, jasná a všem známá pravidla.“ Z rozhovoru s ním vyplývá, že s touto vizí do školy již přicházel a zakládá si na ní stále. Pevnost a důslednost v prosazování vlastní vize však neznamená potlačování svobody rozhodování učitelů v pedagogickém procesu ani nekompromisní postoje. S učiteli diskutuje odborné problémy, podporuje jejich iniciativu a často přijímá i jejich návrhy řešení. Ve škole byla zjištěna

14 Ve shodě s jinými výzkumnými nálezy se potvrzuje, že důvěra má v organizaci vícevrstevný a všesměrný charakter (Brücknerová \& Novotný, 2017) ve smyslu důvěry učitelů k řediteli, důvěry ředitele k učitelům a důvěry mezi učiteli. Navíc se ukazuje, že v ZŠ Rekordní je důvěra velmi silným faktorem fungování školy a je přenášena až na úroveň žáků. 
vysoká míra angažovanosti učitelů, v níž se zřetelně projevuje důraz na práci s žákem. S rodiči hovoří ředitel ZŠ Železné otevřeně, objasňuje jim zvolené postupy. Jeho cílem je mít ve škole dobré vztahy. To se týká jak vedení školy a učitelů, tak rodičů žáků a žáků samotných. Ředitelovu otevřenost a vstř́icnost v komunikaci dokládá výrok učitelky z 1 . stupně: „Nebojím se za panem ředitelem přijít s tím, že prostě mám s něčím problém." Jak sám řekl, ředitel je ve škole proto, aby vytvořil optimální podmínky pro práci učitele. Učitel je ve škole proto, aby vytvořil optimální podmínky pro práci dětí. Výchovná poradkyně a učitelka z 2 . stupně s 28letou praxí se k partnerským vztahům ve škole vyjádřila takto:

Žáci naší školy jsou zvyklí za námi o přestávkách chodit. Důraz na vztahy... Za mnou se velmi často vrací studenti ze SŠ... Povídají, jak se jim tam líbí... Velmi často mluví o tom, že jim chybí ten partnerský př́stup mezi učiteli a studenty. Ř́kají, že si velice cenili těch vztahů tady.

Svou vizi rozvoje vztahů se ředitel snažil na počátku svého vedení naplňovat mj. zavedením skupinových stmelovacích akcí a školení, která nebyla povinná, ale mohli se jich účastnit všichni učitelé z pedagogického sboru. Různé semináře, výjezdy a školení pořádá ředitel pro své zaměstnance dodnes. Z počátku vybíral školení on, dnes už nechává volbu převážně na učitelích. Je přesvědčen, že právě podpora lidí je pro školu nejefektivnější investicí: „Zatímco jiné školy v devadesátých letech nakupovaly učebnice, my jsme investovali do učitelů." Pevný způsob prosazování vize je učiteli zpětně doceňován. Jak sami zmínili, někdy si nebyli jisti rozhodnutím, které ředitel udělal, ale zpětně jsou rádi, že se tak dělo. Učitelé si ředitele váží pro jeho kvalitní práci a jeho nasazení pro školu. Nemají problém za ředitelem s čímkoli přijít. Učitelka s 25letou praxí z 2. stupně ř́ká: „On tou školou naprosto žije, že je to jeho srdeční záležitost bych skoro řekla... Nemá zahrádku, ale má tu školu.“

Zajímavým zjištěním je fakt, že navzdory velmi odlišným stylům jednání obou ředitelů při prosazování koncepce školy jsou učitelé spokojeni, jsou v souladu s ředitelovou vizí a oba přístupy ředitelů vedou k výborným výsledkům jak v otázce prestiže školy mezi rodičovskou veřejností, tak i v projevu angažovanosti učitelů. Důraz na partnerské vztahy a založení vize na vysokých hodnotách se jeví jako klíčové pro utváření příznivého klimatu učitelského sboru. 


\section{Mezilidské vztahy a komunikace}

Učitelský sbor v ZŠ Rekordní hodnotí učitelé jako kompaktní, podle svých vyjádření tzv. táhnou za jeden provaz. Učitelé mají sice $\mathrm{k}$ dispozici kabinety, rádi se však scházejí ve sborovně. Uvádějí, že zde nejsou rozdíly mezi 1. a 2. stupněm, jak to na některých školách bývá. Všichni se zde navzájem respektují a klima učitelského sboru je založeno na přátelských vztazích. Jak uvádí učitelka z 2. stupně s dlouholetou praxí: „Tady není nikdo, kdo háže klacky pod nohy a kterej, když za ním přijdu, mi nepomůže... Je tady ta soudržnost a jsme tady víceméně všichni kamarádi." Hromadně slaví své narozeniny, Den učitelů nebo se někdy neformálně setkávají mimo školu. Ale jak sami ř́ikají, na neformální setkání nemají bohužel tolik času. Učitelka s 37letou praxí potvrzuje ve své výpovědi: „Hlavně my tady máme hrozně dobrý vztahy, takže my tu řešíme věci úplně automaticky, tak nějak to plyne." Učitelé mají dle svých vyjádření volnost jak ve vyučovacích postupech, tak např. i ve výběru učebnic. $V$ rozhovorech se vyjadřovali o vzájemném respektování vyučovacích stylů, vzájemné pomoci, poskytování si materiálů apod. Z výpovědí vyplynulo, že se učitelé vzájemně uznávají a považují za profesionály. V problematických situacích a konfliktech s některými rodiči se soudržnost sboru a podpora učitelů ze strany vedení dle výpovědí učitelů opakovaně potvrzuje.

Učitelský sbor v ZŠ Železné se sám hodnotí také jako velice kompaktní. Učitelé v rozhovorech mluvili o blízkosti, kterou mezi sebou mají, jež je ze strany vedení podporována výjezdy a školeními, které pro ně ředitel pořádá. Sounáležitost uvnitř učitelského sboru dokládá výrok paní učitelky s dlouholetou praxí: „Funguje to tu. Máme to myšlení asi ne stejné, to nejde, ale velmi podobné s těmi kolegy." Mnoho učitelů srovnávalo své vztahy mezi kolegy s ostatními školami a uváděli, že zde mají výjimečné vztahy mezi sebou. Učitelé jsou rozděleni do kabinetů většinou podle předmětů, které vyučují. Podle výpovědí sdílejí učitelé ředitelovu vizi a snaží se ji naplňovat. Uznávají a respektují se mezi sebou. Spolupráce mezi 1. a 2. stupněm je bezproblémová. Učitelé jsou si vzájemně otevřeni a poskytují si materiály, zkušenosti a pomoc. Vztahy ve sboru i s vedením školy jsou i na neformální úrovni. Všichni vypovídající potvrdili, že se schází i mimo školu. Př́́kladem je výpověd' učitele z 2 . stupně s dlouholetou praxí: 
Není problém se tady za kýmkoliv ve sboru zastavit a říct, že mám problém nebo řeším tohle, nejsem si jistý (...) vím, že za kýmkoliv můžu jít a více méně s čímkoliv se na něj obrátit.

V obou porovnávaných školách shledáváme vysoké mínění ředitele o učitelském sboru a jeho důvěru $v$ profesionalitu a kvalitně odváděnou práci při vysoké míře svobody ponechané učitelům $v$ jejich rozhodování a vyučovacím stylu.

V obou případech klade vedení důraz na partnerské, přátelské vztahy uvnitř sboru i celé školy, a to jak v rovině formální - profesní, tak i neformální obecně mezilidské. $\mathrm{V}$ obou případech je posilování těchto vztahů vedením systematicky podporováno cílevědomým organizováním společných vzdělávacích, teambuildingových, kulturních i neformálních akcí pro učitele, podporováním otevřené komunikace a $\mathrm{v}$ neposlední řadě i vlastním příkladem ředitele (ředitel je sám členem týmu).

\section{Závěry}

Učitelský sbor je specifickou sociální skupinou s významným vlivem na fungování a kvalitu školy. Ve smyslu profesního rozvoje je u nás tradičně cílena pozornost k učiteli jako individuu (např. Starý et al., 2012), méně jsou propracovány a prosazovány strategie práce s učitelským sborem jako celkem.

Cílem naší studie bylo v závislosti na parametrech zjištěného sociálního klimatu nalézt a popsat shody a rozdíly mezi vybranými učitelskými sbory ZŠ v jejich charakteristikách a podmínkách fungování. Kvalitativní analýze jsme podrobili dvě dvojice učitelských sborů. Kritériem výběru byly hodnoty jejich sociálního klimatu při současné snaze zachovat obdobné evidentní znaky školy a sboru. První dvojice sborů byla dle kritéria otevřenosti sociálního klimatu vybrána jako dva protipóly, druhá dvojice jako dva sbory s podobným (značně příznivým) sociálním klimatem. Smyslem bylo identifikovat shody a rozdíly v charakteristikách a podmínkách fungování učitelských sborů vybraných škol. Hledány byly klíčové atributy, které by mohly ve sborech vysvětlit zjištěné rozdíly, resp. shody v charakteristikách sociálního klimatu.

V souladu s výzkumnými otázkami jsme hledali příčiny extrémních odlišností sociálního klimatu učitelských sborů (V01), a naopak jevy, které vedou ve zkoumaných školách ke shodám $\mathrm{v}$ charakteristikách klimatu učitelského sboru (VO2). Výzkumné otázky byly pro vybrané dvojice případů zevrubně 
zodpovězeny ve výsledkové části textu. Lze shrnout, že učitelské sbory, u kterých byly identifikovány extrémní rozdíly sociálního klimatu, se odlišují především ve způsobech řízení a vedení lidí, a to ve smyslu přímých zásahů i zprostředkovaných důsledků. Totéž lze v principu konstatovat, máme-li objasnit důvody shodných (a příznivých) hodnot sociálního klimatu dvou sborů „dvojčat“. Určujícím je pro charakteristiky sociálního klimatu učitelských sborů, a to bez ohledu na jeho kvalitu, především pedagogické vedení školy (Dvořák, 2011). ${ }^{15}$

Analýza a konfrontace dat otevřela několik zásadních otázek, které směřují do tematiky pedagogického vedení i mimo tuto oblast a které považujeme pro charakteristiky sociálního klimatu, jeho stabilitu a pro fungování sboru a školy i v obecnějším záběru za významné.

Mezi všemi sledovanými školami se jako nápadné ukázaly rozdíly v pedagogickém vedení, a to i u charakteristikami podobných škol, které jsme označili jako „dvojčata“. I proto byla do kvalitativní komparace tato dvojice zahrnuta. Univerzálně platný úspěšný styl vedení lidí ve školní organizaci je modernějšími paradigmaty odmítán. Bez pochopení specifik personální konstelace a akceptování podmínek a situací, ve kterých sbor pracuje, nelze ani jednoznačně stanovit nejvhodnější kombinaci stylů vedení (Vychopňová, 2017, 11-12). Podobně dokladují zahraniční studie (např. May, Huff, \& Goldring, 2012), že se neukazuje jako jednoznačné, které činnosti vedou v různorodých podmínkách práce školy k žádoucím výsledkům. I proto lze kvalitativně orientované výzkumné aktivity (klimatu) školy považovat za př́nosné pro rozvoj teorie i pro praktický provoz školy.

Zjevné opakované nerespektování specifik učitelského sboru v malé škole spolu s neochotou sboru dovedly po pěti letech Žulovou až k manažerskému krachu. Její vedení volilo manažersky chybné, vzhledem k podmínkám a situaci jejichž efekt byl mnohdy kontraproduktivní. Přitom lze konstatovat, že vedení školy věnovalo pedagogické práci značné úsilí i čas, což je pro české prostředí, jak např. uvádí Trojan (2018), z důvodu zaneprázdnění jinými činnostmi ředitelů, spíše netypické. Zanedbávána však byla v Žulové přímá práce s lidmi, a to jako důsledek dlouhodobé interakční izolovanosti mezi vedením a sborem. $V$ profesních interakcích ze strany vedení převažovaly spíše

15 Ve shodě s jinými autory (např. u nás Dvořák, 2011; Sedláček, 2011; v zahraničí Leithwood, 2005, a další) se přikláníme k širšímu pojetí pojmu pedagogického vedení školy, ve smyslu transformujícího vedení a zohledňující celý systém školy i s jeho kontexty. 
autoritativní praktiky příkazů, nedůvěry, kontroly apod., které ovšem mohou přinášet také negativní efekty, jak bylo v některých zahraničních studiích výzkumně prokázáno (Grissom, Loeb, \& Master, 2013).

Zcela zásadní pro kvalitu sociálního klimatu i pro příznivé efekty vedení učitelských sborů se ukazuje vytvářená shoda na hlavních principech chodu školy, sdílení jasné vize rozvoje školy, podporující styl vedení a prostor vytvářený pro práci učitele. Zatímco však byla shoda identifikována explicitně v Železné a v Rekordní (velmi nízká variabilita v hodnocení klimatu sborem; konzistence věcných výpovědí i „formálního jazyka“ vedení, učitelů a žáků školy aj.), ZŠ Žulová tento požadavek, stejně jako sdílení a podporu evidentně nenaplňovala.

Geneze a vývoj byl u zkoumaných škol sledován a popsán na úrovni managementu. Nabízí se ale také otázka, jaký je původ učitelského sboru, jak byl vytvářen, resp. vedením školy formován. Sborovny ve školách v souvislosti s fluktuací či nedostatkem učitelů naplňují zpravidla náhodné sestavy učitelů. Přesto se ze strany vedení Sibiřské i Železné ukazovaly zřejmé snahy záměrného výběru učitelů, resp. dlouhodobého budování učitelského sboru. Považujeme to za silný stabilizující faktor, nikoliv však snadno realizovatelný v prostředí současné školy.

V souvislosti s vedením lidí se z našich dat vynořily další podpůrné fenomény, které lze považovat za nosné, a jak se ukázalo, mohou se pro některé školy stát i principem podpory fungování učitelského sboru. Jde o důvěru mezi aktéry školního života (Brücknerová \& Novotný, 2017), o společné sdílení jako jeden ze znaků kultury školy (Pol et al., 2004, s. 47-58) a o otevřenou komunikaci mezi vedením školy a učitelským sborem (Lukas, 2009) i uvnitř sboru. K jejich naplnění, jak se ukázalo, mohou vést různé, zdánlivě i protichůdné cesty. Vyšší hodnoty direktivity a pevná pravidla jako důsledek silně prosazované vize přispěly při dostatečné souběžné podpoře učitelů ke shodě na principech chodu školy (Železná). K témuž výsledku se propracoval i liberálnější př́ístup vedení lidí v ZŠ Rekordní založený na značně široké a všesměrné důvěře mezi aktéry školního života, s volnějšími organizačními mantinely a s důrazem na morální aspekt „samokontroly“ a zodpovědnosti jednotlivých učitelů. ${ }^{16}$ Obě školy povyšují kombinací identifikovaných atribu-

16 Když Brücknerová a Novotný (2017) zkoumali v souvislostech mezigeneračního učení téma důvěry uvnitř (pedagogického) sboru, ukázalo se, že sice tento fenomén nemusí být vždy nutně produktivní pro práci školy, ale klíčový dopad má důvěra učitelů k vedení školy. 
tů vlastní organizaci až na úroveň pospolitosti, tak jak ji vymezuje Pol (2007, s. 21-23). V uvedených souvislostech je nutné zdůraznit, že k úrovni pospolitosti vede dlouhodobá práce v relativně stabilizovaných podmínkách školní organizace a že pospolitost významně subsumuje všechny aktéry školního života, tedy kromě učitelů také žáky. $V$ souladu s některými zahraničními zjištěními (Sun et al., 2013) lze i u námi zkoumaných škol předpokládat, že kvalitní pedagogické vedení působí na sbor, podporuje jeho př́znivé klima a prostupuje až na úroveň učební činnosti a výsledků práce žáků (Leithwood et al., 2006). ${ }^{17}$

Faktor velikosti školy bývá v souvislosti se sociálním klimatem sboru intuitivně přeceňován. Malé sbory (potažmo i malé skupiny žáků takových škol) mohou sice edukačně i sociálně úspěšně profitovat z „rodinné atmosféry“, jak by se mohlo zdát v př́padě Sibiřské, avšak ani zde nebyla velikost školy tím klíčovým faktorem excelentního sociálního klimatu sboru. Malé školní organizaci odpovídal především způsob a kvalita jejího řízení a vedení lidí. Tedy to, co se právě manažersky nedařilo (též v malé) ZŠ Žulové. Rozhodujícím faktorem pozitivních posunů a proměn (i malé) školy je adekvátnost jejího řízení a stylu vedení lidí vzhledem k podmínkám a situaci, ve které se škola nachází. K podobným závěrům se u nás přiklánějí i dřivější zjištění Dvořáka, Starého a Urbánka (2015). Malé školy (v malých sídlech) jsou zpravidla úžeji a jinými vztahy vázány ke své lokalitě i ke zřizovateli a interakční vzorce uvnitř malých sborů jsou determinovány interakcemi mezi malou školou a vesnickou komunitou (Pietarinen \& Meriläinen, 2008). Přesto, že uvedení autoři hodnotí málotřídní školy v odlišném kulturním prostředí, lze i na naši situaci vztáhnout uvedenou specifičnost malých škol s tvrzením, že důsledky těchto specifických vazeb mohou být silně pozitivní i silně negativní (jak se nakonec exemplárně ukazuje v př́ípadě ZŠ Sibiřské vs. ZŠ Žulové).

Fungování učitelského sboru stojí nepřímo také na vztahu mezi vedením školy a „politikou“ jejího zřizovatele, kde svou roli může hrát velikost obce, resp. vyšší počet (konkurenčních) škol v místě. I přes výborné výsledky, dobrou pověst a korektní vztahy ke zřizovateli byly v obou základních školách

17 My se v našem textu dopadem vedení školy na učení žáků explicitně nezabýváme. Avšak i přes určitou rozporuplnost výzkumných výsledků, o kterých referuje Dvořák (2011, s. 21), předpokládáme ve shodě s vlivnými zahraničními výzkumy, že vedení školy (Leithwood et al., 2006; Leithwood \& Jantzi, 2008), resp. především obecné manažerské kompetence ředitele (Grissom \& Loeb, 2011), jsou velmi významným prvkem, který zejména nepřímými mechanismy ovlivňuje i výsledky učení žáků. 
s výrazně příznivým klimatem a kvalitním vedením (Železná, Rekordní) zaznamenány velmi podobné obavy ředitelů z hodnocení zřizovatelem a snaha stále i formálně potvrzovat vlastní vysokou prestiž a kvalitu. Existenční závislost i úspěšných škol na decizních počinech zřizovatele dokládá dlouhodobý problém nevyváženosti odborného a politického řízení na této úrovni. Významnost vztahu školy a zřizovatele i s dopady na sbor dokládá i protikladná dvojice škol. Sibiřská, kde byla ředitelka současně i místostarostkou, mohla jistě těžit z těchto úzkých personálních vazeb. Vztah vedení školy Žulové ke zřizovateli se jevil jako krajně submisivní s implicitní nadějí vnější podpory při řešení problematických vztahů se sborem.

Uvedené výsledky naší studie mají přirozeně své limity. Výzkumný koncept nedovoluje vyšší stupeň zobecnění a výsledky jsou navíc omezeny možnostmi a kritérii výběru učitelských sborů, na což již bylo upozorněno v metodologické části textu.

\section{Literatura}

Bergman, M. M. (2011). O nezbytnosti třetí generace ve smíšeném designu, teorii a výzkumu: o překonávání nekompatibility kvalitativního a kvantitativního výzkumu. Pedagogická orientace, 21(4), 457-473.

Brücknerová, K., \& Novotný, P. (2017). Trust within teaching staff and mutual learning among teachers. Studia paedagogica, 22(2), 67-95.

Bush, T., \& Glover, D. (2014). School leadership models: what do we know? School Leadership \& Management, 34(5), 553-571.

Čech, T. (2011). Mobbing jako negativní fenomén v prostredí základních škol. Brno: Masarykova univerzita.

Dvořák, D., Starý, K., Urbánek, P., Chvál, M., \& Walterová, E. (2010). Česká základní škola: víceprrípadová studie. Praha: Karolinum.

Dvořák, D. (2011). Pedagogické vedení školy: hledání zdrojů a obsahu pojmu. Orbis scholae, 5(3), 9-25.

Dvořák, D., Urbánek, P., \& Starý, K. (2014). High autonomy and low accountability: Case study of five Czech schools. Pedagogická orientace, 24(6), 919-940.

Dvořák, D., Starý, K., \& Urbánek, P. (2015). Malá škola po pěti letech: proměny školy v době reformy. Pedagogická orientace, 25(1), 9-31.

Gavora, P. (2010). Úvod do pedagogického výzkumu. Brno: Paido.

Gavora, P. (2015). Obsahová analýza v pedagogickom výskume: pohlad na jej súčasné podoby. Pedagogická orientace, 25(3), 345-371.

Grecmanová, H., Dopita, M., Kantorová, J., Skopalová, J., \& Chvál, M. (2013). Organizační klima fakult připravujících učitele. Olomouc: UP v Olomouci. 
Grissom, J. A., \& Loeb, S. (2011). Triangulating principal effectiveness: How perspectives of parents, teachers and assistent principals identify the central importance of managerial skills. American Education Research Journal, 48(5), 1091-1123.

Grissom, J. A., Loeb, S., \& Master, B. (2013). Effective instructional time use for school leaders: Longitudinal evidence from observations of principals. Educational Researcher, 42(8), 433-444.

Halpin, A. W., \& Croft, D. B. (1963). The organizational climate of schools. Chicago: Midwest Administration Center.

Harris, A., \& Chapman, C. (2002). Democratic leadership for school improvement in challenging context. International Electronic Journal for Leadership in Learning, 6(9),1-12.

Hendl, J. (2005). Kvalitativní výzkum: základní metody a aplikace. Praha: Portál.

Ježek, S. (2003). Možnosti konceptualizace školního klimatu. In S. Ježek (Ed.), Psychosociální klima školy I (s. 2-3). Brno: Masarykova univerzita.

Kirkbride, P. (2006). Developing transformational leaders: The full range leadership model in action. Industrial and Commercial Training, 38(1), 23-32.

Kotátková, S. (2009). Kvalita sociálního klimatu a potřeby učitelek mateřských škol. Studia paedagogica, 14(2), 69-84.

Kottkamp, R. B., Mulhern, J. A., \& Hoy, W. K. (1987). Secondary school climate - a revision of the OCDQ. Educational Administration Quarterly, 23(3), 31-48.

Lašek, J. (1995). Prvé skúsenosti s meraním klímy v škole a učitel'skom zbore. Pedagogická revue, $47(1,2), 43-50$.

Lašek, J. (2001). Sociálně psychologické klima školních tříd a školy. Hradec Králové: Gaudeamus.

Lazarová, B. (Ed.) (2011). Pozdní sběr: o práci zkušených učitelů. Brno: Paido.

Leithwood, K. (2005). Educational leadership: A review of research. Philadelphia: LSC, Temple University.

Leithwood, K., Day, C., Sammons, P., Harris, A., \& Hopkins, D. (2006). Seven strong claims about successful school leadership. Nottingham: National College for School Leadership.

Leithwood, K., \& Jantzi, D. (2008). Linking leadership to student learning: The contributions of leader efficacy. Educational Administration Quarterly, 44(4), 496-528.

Lukas, J. (2009). Vztahy mezi učiteli a řediteli na základních školách - přehled relevantních výzkumů. Studia paedagogica, 14(1), 127-145.

Lukášová, H. (2015). Učitelské sebepojetí a jeho zkoumání. Zlín: FHS UTB.

Mareš, J. (2001). Sociální klima školy. In J. Čáp \& J. Mareš, Psychologie pro učitele (s. 581-596). Praha: Portál.

Mareš, J. (2003). Zamyšlení nad pojmem klima školy. In Ježek, S. (ed.) Psychosociální klima školy I (s. 87-98). Brno: Masarykova univerzita.

Mareš, J. (2015). Tvorba př́padových studií pro výzkumné účely. Pedagogika, 65(2), 113-142.

May, H., Huff, J., \& Goldring, E. (2012). A longitudinal study of principals' activities and student performance. School Effectiveness and School Improvement, 23(4), 1-23.

Miovský, M. (2006). Kvalitativní př́stup a metody v psychologickém výzkumu. Praha: Grada.

Novotný, P., \& Brücknerová, K. (2016). Informální mezigenerační učení v učitelských sborech: rozdíly v zapojení generací do učebních interakcí. Orbis scholae, 10(1), 11-33. 
Pietarinen, J., \& Meriläinen, M. (2008). Aktivní a pasivní fáze kariéry učitele v kontextu malotřídní školy. Studia paedagogica, 13(1), 65-83.

Píšová, M., Najvar, P., Janík, T., Hanušová, S., Kostková, K., Janíková, V., ... Zerzová, J. (2011). Teorie a výzkum expertnosti v učitelské profesi. Brno: Masarykova univerzita.

Pol, M., Hloušková, L., Novotný, P., \& Zounek, J. (2003). K základům úspěchu v řízení škol: o práci ředitelů škol s vizí. In Sborník prací filozofické fakulty brněnské univerzity, U 8 (s. 87-102). Brno: Masarykova univerzita.

Pol, M., Hloušková, L., Novotný, P., Sedláček, M., \& Zounek, J. (2004). Vnitřní a vnější souvislosti fungování školy a její kultury. In Sborník prací filozofické fakulty brněnské univerzity, U 9 (s. 47-58). Brno: Masarykova univerzita.

Pol, M. (2007). Škola v proměnách. Brno: Masarykova univerzita.

Průcha, J. (2002). Učitel. Současné poznatky o profesi. Praha: Portál.

Průcha, J. (2015). Přehled pedagogiky. Úvod do studia oboru. Praha: Portál.

Průcha, J., Walterová, E., \& Mareš, J. (2013). Pedagogický slovník. Praha: Portál.

Rozkovcová, A., \& Novotová, J. (2018, v tisku). Styly vedení školy a sociální klima učitelských sborů základních škol. Orbis Scholae, 12(3).

Schründer-Lenzen, A. (2013). Triangulation - ein Konzept zur Qualitätssicherung von Forschung. In B. Friebertshäuser, A. Langer, \& A. Prengel, A. (Eds.), Handbuch. Qualitative Forschungsmethoden in der Erziehungswissenschaft (s. 149-158). Weinheim: Beltz Juventa.

Sedláček, R. (2011). Pedagogické vedení školy v pojetí ředitelů základních škol. Orbis scholae, 5(3), 27-42.

Spilková, V., \& Vašutová, J. (Eds.). (2008). Učitelská profese $v$ měnících se požadavcích na vzdělávání. Praha: PedF UK.

Starý, K., Dvořák, D., Greger, D., \& Duschinská, K. (2012). Profesní rozvoj učitelů. Podpora učitelů pro zlepšování výsledků žáků. Praha: Karolinum.

Sun, M., Frank, K. A., Penuel, W. R., \& Kim, C. M. (2013). How external institutions penetrate schools through formal and informal leaders. Educational Administration Quartely, 49(4), 610-644.

Švaříček, R., \& Šed’ová, K., et al. (2007). Kvalitativní výzkum v pedagogických vědách. Praha: Portál.

Švaříček, R. (2009). Pomluvy jako mikropolitická strategie učitelů základní školy. Studia paedagogica, 14(1), 87-108.

Trojan, V. (2018). Pedagogický proces a jeho ř́zení. Praha: Wolters Kluwer.

Urbánek, P. (2006). Klima učitelských sborů ZŠ: empirická zjištění. In Kocurová, M. (Ed.). Současné metodologické př́stupy a strategie pedagogického výzkumu. Sborník příspěvkủ 14. konference ČAPV. Plzeň: PedF ZČU. Dostupné z http://www.kpg.zcu.cz/capv/HTML/105/ default.htm

Urbánek, P. (2008). Klima učitelského sboru v případové studii základní školy. Orbis scholae, 3(3), 87-106.

Urbánek, P. (2011). Učitelské sbory základních škol: dvě odlišné profesní subkultury. In E. Walterová (Ed.), Dva světy základní školy? Úskalí přechodu z 1. na 2. stupeň (s. 269-294). Praha: Karolinum.

Urbánek, P., Dvořák, D., \& Starý, K. (2014). Dynamika sociálního klimatu učitelských sborů v době reformy. Orbis scholae, 8(1), 65-78. 
Urbánek, P., Picek, J, Jursová, J., Novotová, J., Picková, H., \& Rozkovcová, A. (2017). Výzkum učitelských sborů ZŠ: potenciál výběrových šetření, problematika výběru a vstupu do terénu. In I. Žlábková (Ed.), Sborník konference ČAPV. České Budějovice: PF JU.

Urbánek, P. (2018). Učitelský sbor české základní školy. Orbis Scholae, 12(3).

Vašutová, J. (2004). Profese učitele v českém vzdělávacím kontextu. Brno: Paido.

Vychopňová, T. (2017). Vedení lidí ve školách v kontextu teorie sociální moci. Lifelong learning, $7(3), 7-20$.

\title{
Autoři
}

PaedDr. Jitka Jursová, Ph.D., Technická univerzita v Liberci, Fakulta přírodovědně-humanitní

a pedagogická, katedra pedagogiky a psychologie, Studentská 1402/2, 46001 Liberec,

e-mail: jitka.jursova@tul.cz

doc. PaedDr. Petr Urbánek, Dr., Technická univerzita v Liberci, Fakulta přírodovědně-humanitní a pedagogická, katedra pedagogiky a psychologie, Studentská 1402/2, 46001 Liberec,

e-mail: petr.urbanek@tul.cz

Mgr., Bc. Markéta Váchová, Univerzita Karlova, Pedagogická fakulta, Ústav výzkumu a rozvoje vzdělávání, Myslíkova 7, 11000 Praha 1, e-mail: MarkytkaVachova@seznam.cz

\section{Variability of the Teaching Staff Social Climate in Basic Schools with Differing Work Conditions}

\begin{abstract}
The aim of the study is to identify and describe sameness and differences among selected school teaching staffs concerning their characteristics and functioning in the context of found parameters of their teaching staff social climate. The aim is to find the causes of the found climate parameters and confront the evident and more hidden characteristics of the staffs. The data from the quantitative research phase were used as a base for further qualitative procedures. Two pairs of basic school teaching staffs were selected - one pair with very different parameters of the social climate (favourable and unfavourable), the other pair with similar (favourable) parameters of the climate. In both pairs the climate was favourable. The form of vision sharing and school functioning, leadership style and its genesis, interpersonal relationships and communication, teacher commitment and its support.
\end{abstract}

Similar parameters of the social climate in schools do not mean the same factors in the organization and work conditions in individual schools. Especially noticeable are different pedagogical leadership styles at schools with very similar parameters of the teaching staff social climate. The key attribute for optimal leadership seems to be the concord of the leadership style with each of the specific and unique teaching staff. The essential factors for the staff social climate quality are the ever-forming 
concord about the main principles of school functioning, sharing a clear vision of school development, supporting leadership style and purposefully created space for the teacher's work. The ways to achieve the optimal staff climate can vary and under specific life conditions of every school a very original and complicated organism is created.

Key words: basic school, teaching staff, social climate, qualitative research, comparison 